\title{
Clinical and Radiological Significance of Transient Brain Lesion in the Corpus Callosum Splenium: 2 Case Reports
} \section{Korpus Kallozum Spleniumda Görülen Geçici Beyin Lezyonun Klinik ve Radyolojik Önemi: 2 Olgu Sunumu}

\author{
Fettah Eren', Gözde Öngün², Șerefnur Öztürk² \\ ${ }^{1}$ University of Health Sciences, Konya Education and Research Hospital, Neurology; ${ }^{2}$ Selçuk University Faculty of Medicine, Neurology, \\ Konya, Turkey
}

\begin{abstract}
Although rare, splenium of the corpus callosum (SCC) may be involved in many etiological conditions. Most forms of involvement are permanent and minorities of these are transient. The pathophysiology is intra-myelinic axonal edema related to hyponatremia and local inflammatory cell infiltration. The first case; 34-years-old female patient accepted to our unit with recurrent complex-partial seizures. She had epilepsy for 10 years and carbamazepine using for 4 years. Second case; 22-years-old female patient presented with vomiting, nausea and visual deficiency. Both cases magnetic resonance imaging (MRI) showed focal diffusion limitation in SCC. A comprehensive diagnostic work-up was carried out to account for these clinical and neuro-radiological presentations. 1-month follow up MRI showed resolution of these lesions. Previously, transient limitation of diffusion of SCC has been mostly reported in epileptic patients and treatment with anti-epileptic agents. However, many other conditions may result the appearance of similar clinical states. These patients may have mild form of encephalopathy and the prognosis is generally good. MRI is particularly sensitive in early identification of these lesions. A good understanding of the transient nature of the condition may allow avoidance from unnecessary invasive diagnostic and therapeutic methods.
\end{abstract}

Key words: corpus callosum; splenium; transient lesion; magnetic resonance imaging

\section{ÖZET}

Korpus kallozumun spleniumu (KKS), birçok etiyolojik neden ile nadir de olsa etkilenebilmektedir. Bu tutulumun bir kısmı kalıcı ve az bir kısmı da geçicidir. Patofizyolojisinde hiponatremi ile ilișkili intramiyelinik aksonal ödem ve lokal inflamatuar hücrelerin infilitrasyonu vardır. Birinci olgu; 34 yașında kadın hasta, tekrarlayan kompleks parsiyel nöbetler ile bașvurdu. Özgeçmișinde, 10 yıldır epilepsi hastalığı ve 4 yıldır karbamazepin kullanımı vardı. İkinci olgu; 22 yașında kadın hasta bulantı kusma ve görme bozukluğu

Fettah Eren, University of Health Sciences, Konya Education and Research Hospital, Neurology, Konya, Turkey, Tel.05058604146Email.dreren42@hotmail.com Geliş Taribi: 23.10.2017 • Kabul Taribi: 20.07.2018 șikayetleri ile bașvurdu. Kranial manyetik rezonans görüntüleme (MRG)'lerinde KKS'de fokal difüzyon kısıtlamaları izlendi. Bu klinik ve nöroradyolojik görünüme sebep olabilecek diğer tüm faktörler araștırıldı. Bir ay sonraki kranial MRG incelemelerinde bu lezyonların düzelmiș olduğu görüldü. KKS'nda geçici difüzyon kısıtlamaları daha çok epilepsi hastalarında ve antiepileptik ilaç kullanımlarında bildirilmiștir. Fakat birçok durum benzer görüntüye sebep olabilmektedir. Bu olgularda hafif bir ensefalopati görülebilir ve prognoz genellikle iyidir. MRG bu lezyonların erken dönemde saptanmasında oldukça duyarlıdır. Bu klinik durumun geçici olduğunu bilmek, girișimsel tanı ve tedavi yöntemlerinden kaçınmamızı sağlayabilir.

Anahtar kelimeler: korpus kallozum; splenium; geçici lezyon; manyetik rezonans görüntüleme

\section{Introduction}

Transient lesions of the splenium of corpus callosum (SCC) are a rare phenomenon that may occur in a variety of conditions. Morphologically these lesions are located in the middle portion of SCC, are oval shaped, and have a well-demarcated boundary. These lesions are unlikely to enlarge and attain a hemorrhagic character, and follow-up imaging studies generally do not show new occurrence of concomitant lesions. Magnetic resonance imaging (MRI) shows hyper-intensity in T1 and FLAIR sequences, while T2 sequences are hypo-intense. In addition, focal diffusion is restricted in diffusion weighed MRI images. On the other hand, cranial computed tomography (CT) may be unremarkable ${ }^{1}$. Cytotoxic edema is the most frequent culprit in the etiopathogenesis of such lesions, and may result from the toxic effects of a variety of drugs, and mainly anti-epileptics. Additionally, systemic, metabolic, or infectious diseases may lead to a similar appearance in conjunction with focal demyelination. Clinically, 

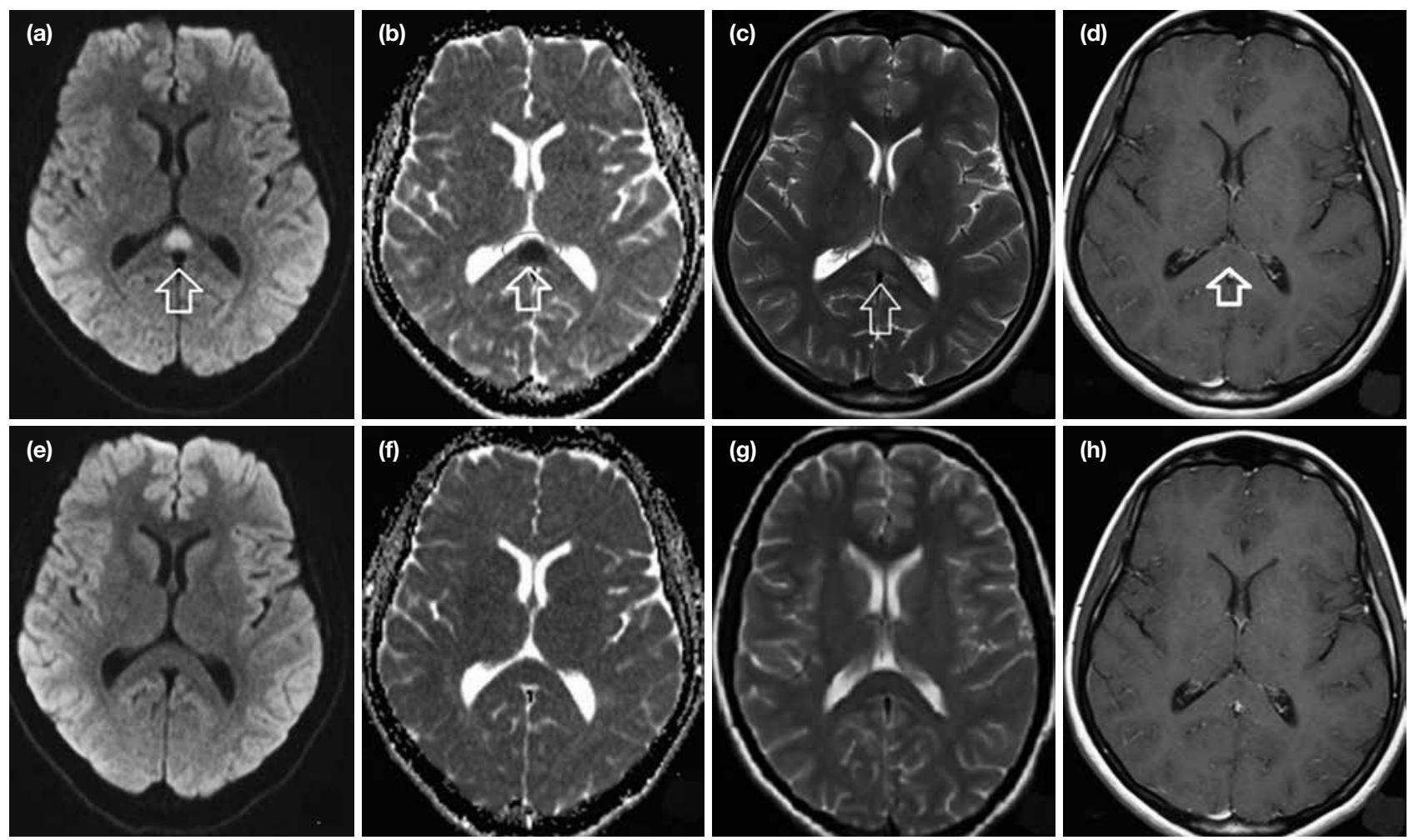

Figure 1. a-h. Magnetic resonance imaging of case 1: Initially (a-d); 10 days later (e-h). Diffusion weighed image (a, e); ADC mapping (b, f); T2 sequence (c, g); T1 sequence+post-contrast $(\boldsymbol{d}, \boldsymbol{h})$; The lesion in the splenium of corpus callosum resolved after 10 days.

patients may present with encephalopathy with signs of mild impairment of consciousness ${ }^{2,3}$. However, until now no explanations for the preferential involvement of this anatomical location could be provided. We discussed the radiological characteristics, risk factors, and prognosis of this rare entity in the context of two case reports with clinically different features.

\section{Cases}

First patient: A 34-year old female patient presented with recurrent complex-partial seizures. She had a epilepsy for 10 years and carbamazepine history for 4 years at a daily dose of $1200 \mathrm{mg}$. On average, she reported having two seizure episodes per month that begin in the right or left arm, evolving to a secondarily generalized seizure. She also reported inadequate compliance to anti-epileptic treatment. She was admitted because of increased frequency of seizures (i.e. two episodes per day) to secondarily generalized seizures. In addition, she had received phenytoin infusion at a dose of $18 \mathrm{~g} / \mathrm{kg}$ over 30 minutes at the emergency room, due to the failure to control the epileptic activity. Diffusion weighed MRI showed a focal hyper-intense lesion of $12 \times 10 \mathrm{~mm}$ within SCC with well-demarcated margins. In apparent diffusion coefficient (ADC) mapping, the corresponding anatomical parts exhibited hypointense character. T2 MRI sequence of the same lesions showed hyper-intensity. No pathological contrast enhancement was found after injection of intravenous contrast medium in $\mathrm{T} 1$ MRI sequences (Fig. 1. a-d). Electroencephalography (EEG) was normal. Laboratory tests results were as follows: white blood cell (WBC) $7.81=\mathrm{K} / \mathrm{uL}$ (3.510.5), hemoglobin=11.2 g/dl (13.5-17.5), platelets $(\mathrm{PLT})=22 \mathrm{~K} / \mathrm{uL}(150-450), \mathrm{B} 12=444 \mathrm{pg} / \mathrm{ml}$ (211-911), folic acid=8.62 $\mathrm{ng} / \mathrm{ml}$ (9-24). Routine biochemistry analyses showed normal. In addition to carbamazepine at a dose of $1200 \mathrm{mg} /$ day, levetiracetam $1000 \mathrm{mg} /$ day was added to the treatment and seizures were adequately controlled. A diffusion weighed MRI after 10 days showed resolution of the lesion in ACD mapping and in T2 sequences, while no difference was found as compared to the image obtained at presentation 10 days ago in $\mathrm{T} 1$ sequences after contrast injection (Fig. 1. e-h). 



Figure 2. a-h. Magnetic resonance imaging of case 2: Initially (a-d); 10 days later (e-h). Diffusion weighed image (a, e); ADC mapping (b, f); T2 sequence (c, $\mathbf{g})$; FLAIR sequence $(\boldsymbol{d}, \boldsymbol{h})$; The lesion in the splenium of corpus callosum resolved after 10 days.

Second patient: A 22-year-old female patient presented with vomiting, nausea, and impaired vision. Neurological examination was normal. She had no chronic disease history of medical conditions. Diffusion weighed MRI showed a 9x11 mm focal, hyper-intense lesion with well-defined margins in SCC. ADC mapping showed hypo-intensity in the same lesion. T2 and FLAIR sequences showed focal hyper-intensity as well as the absence of pathological contrast enhancement (Fig. 2. a-d). EEG revealed normal. Laboratory results were as follows: $\mathrm{WBC}=8 .{ }^{71} \mathrm{~K} /$ Ul (3.5-10.5), hemoglobin=16.3 g/dl (13.5-17.5), $\mathrm{PLT}=235 \mathrm{~K} / \mathrm{Ul}(150-450), \mathrm{B} 12=153 \mathrm{pg} / \mathrm{ml}(211-$ 911), folic acid=18.12 ng/ml (9-24). Routine biochemistry testing showed normal too. Blood, urine, throat, and cerebrospinal fluid (CSF) cultures revealed no microbiological growth. Other test results were as follows: anti $\mathrm{CCP}=$ negative, anti $\mathrm{ds}-\mathrm{DNA}=$ negative, antinuclear antibodies (ANA)=negative, anti-neutrophil cytoplasmic antibodies $(\mathrm{ANCA})=$ negative, rheumatoid factor $(\mathrm{RF})=11.6 \mathrm{mg} / \mathrm{L}(0-20)$ and anticardiolipin IGM/IGG=negative. Erythrocyte sedimentation rate $(E S R)=12 \mathrm{~m} / \mathrm{h}(0-20)$, C-reactive protein $(\mathrm{CRP})=5.27 \mathrm{mg} / \mathrm{L}(0-5)$, immunoglobulin $\mathrm{G}=12 \mathrm{~g} / \mathrm{l}(7-16)$, immunoglobulin $\mathrm{M}=1.28 \mathrm{~g} / \mathrm{L}$ (0.42.3). CSF protein $=33.6 \mathrm{mg} / \mathrm{dl}(15-85)$, immunoglobulin $\mathrm{G}$ index $=0.3(>0.85)$ and polymerase chain reaction $(\mathrm{PCR})=$ negative. No oligoclonal bands $(\mathrm{OCB})$ were detected in CSF. Microscopic examination of CSF was acellular. The visual evoked potential (VEP) latencies were normal. After 15 days, T2/FLAIR MRI and diffusion weighed MRI were repeated and showed resolution of the focal SCC lesion (Fig. 2. e-h).

\section{Discussion}

Although SCC involvement does not indicate the presence of a specific disorder, certain conditions may be associated with lesions at this anatomical site. Variety of local or systemic infections may affect SCC. Initially the patient may present with nonspecific signs and symptoms such as mildly increased body temperature, nausea, vomiting, headache, nasal congestion, and mild mental changes. However, in some patients the clinical presentation may take a 
more dramatic form with more severe mental alterations and epileptic seizures ${ }^{4,5}$.

The reason for the specific involvement of this anatomical site and its pathophysiological mechanisms are yet to be elucidated. Implicated factors include cytotoxic edema, focal inflammatory changes, electrolyte alterations at the cell membrane and focal demyelination due to antiepileptic drugs. Isolated involvement of SCC is not due to a difference between the histopathological characteristics of this region and other parts of the corpus callosum. Vascular theory has been able to partly explain the specific involvement at this site, since SCC is supplied by the vertebrobasilar system, while other parts of the corpus callosum receive their circulation via the carotid system. However, absence of lesions in other areas supplied by the vertebrobasilar system is one shortcoming of the vascular theory ${ }^{2,6,7}$.

The specific involvement of this site occurs more commonly in certain patients, particularly epileptic patients and those receiving anti-epileptic agents. In such patients, restricted diffusion may be observed in diffusion weighed images, possibly in association with the alterations in fluid-electrolyte balance induced by antiepileptic medications. In particular, carbamazepine may trigger strong diuretic effects via its effects on arginine-vasopressin system ${ }^{8,9}$. So affecting the cell membrane and causing cytotoxic edema lead to the occurrence of the SCC lesion. As with our first patient, it should be borne in mind that long term use of carbamazepine may be associated with such lesions, especially after frequently recurring seizures. However, the effect of this condition on prognosis and treatment efficacy is not clear. EEG can show slowed brain activity and sharp waves especially in the posterior occipitotemporal portion. Some of the patients may not have any EEG abnormalities ${ }^{5,10}$. Our first patient manifested recurrent convulsions without EEG wave disturbances. Second patent did not have epilepsy and EEG was normal.

Differential diagnoses in patients with SCC involvement include ischemic cranial disorders, intoxication, Marchiafava-Bignami disease, hydrocephalus, acquired immune deficiency syndrome (AIDS), lymphoma, posterior reversible encephalopathy syndrome (PRES), and multiple sclerosis (MS). The high number of differential diagnoses may complicate efforts at elucidating the etiology of the condition ${ }^{10}$. When a diagnostic uncertainty exists, as in our second patient, CSF may have to be examined, although there is no consensus on the timing of CSF examination. Lumbar puncture was made to our patient on 7 th day of appected to hospital after results of other tests. When detailed history taking and clinical and electrophysiological findings fail to provide a specific diagnosis, the patient may be followed up with MRI in association with treatment directed at symptoms. When specific diagnoses cannot be established, it may be important to remember the transient nature of this clinical condition to avoid from unnecessary diagnostic and therapeutic interventions.

These cases has been presented in 51. national neurology congress as a poster, in Antalya/Turkey (02.11.2015)

\section{References}

1. Bourekas EC, Varakis K, Bruns D, Christoforidis GA, Baujan M, Slone HW, et al. Lesions of the corpus callosum: MR imaging and differential considerations in adults and children. American Journal of Roentgenology 2002;179(1):251-57.

2. Marsala SZ, Antichi E, Pistacchi M, Gioulis M, Candeago RM, Montemurro RT, et al. Mild encephalitis with a reversible splenial lesion: A clinical benign condition, often underrecognized-Clinical case and literature review. Journal of neurosciences in rural practice 2017;8(2):281.

3. Maeda M, Shiroyama T, Tsukahara H, Shimono T, Aoki S, Takeda K. Transient splenial lesion of the corpus callosum associated with antiepileptic drugs: evaluation by diffusionweighted MR imaging. Eur Radiol 2003;13:1902-6.

4. Fukuda S, Kishi K, Yasuda K, Sejima H, Yamaguchi S. Rotavirusassociated encephalopathy with a reversible splenial lesion. Pediatr Neurol 2009; 40:131-3.

5. Tada H, Takanashi J, Barkovich AJ, Oba H, Maeda M, Tsukahara H, et al. Clinically mild encephalitis/encephalopathy with a reversible splenial lesion. Neurology 2004;63:1854-8.

6. Wilson CA, Mullen MT, Jackson BP, Ishida K, Messé SR. Etiology of corpus callosum lesions with restricted diffusion. Clinical neuroradiology 2017;27(1):31-7.

7. Kakou M, Velut S, Destrieux C. Arterial and venous vascularization of the corpus callosum. Neurochirurgie 1998;44:31-7.

8. Starkey J, Kobayashi N, Numaguchi Y, Moritani T. Cytotoxic lesions of the corpus callosum that show restricted diffusion: Mechanisms, causes, and manifestations. Radiographics 2017;37(2):562-76.

9. Krause $\mathrm{KH}$, Rascher W, Berlit P. Plazma arginine vasopressin concentrations in epileptics under monotherapy. J Neurol 1983;230:193-6.

10. Al-Hashim AH, Blaser S, Raybaud C, MacGregor D. Corpus callosum abnormalities: neuroradiological and clinical correlations. Developmental Medicine \& Child Neurology 2016;58(5):475-84. 